\title{
Quest and Assessment for Self-Identity in the Select Novel of Arun Joshi
}

\section{P. Revathy ${ }^{1}$ and V. Peruvalluthi ${ }^{2}$}

${ }^{1}$ Dept. of English, Muthurangam Government Arts College, Vellore-2, India; and ${ }^{2}$ English Reader, Thiruvalluvar University, Serkadu, India.

*Correspondence: revathy2014@gmail.com (Dr. P. Revathy, Assistant Professor, Dept. of English, Muthurangam Government Arts College, Vellore-2, India).

\begin{abstract}
Literature is one among the fine arts like painting, sculpture and music which express emotions, feelings, humour and happiness using language as a medium of communication through different sorts of genre like prose, poetry, drama and novel. It reflects the items that happen within the society and life. It deals with human being's personal experience, nature, war, culture, imagination, history, etc. Indian English literature is that the outcome of the works written by the Indian author who write in English. In India there are numerous languages and different literatures. Arun Joshi deals with a very difficult situation of a modern man and is sensitively alive to the various dimensions of tortures, exerted by the difficult character and demands of the society in which same age man is destined to live. The heroes of his novels are helpless outsiders and the harsh strangers. The consciousness of man's rootlessness and new feeling and the major search for a meaningful self is the key factor of Joshi's novels.
\end{abstract}

Keywords: Modern man, Foreigner, Billy Biswas, Self-Identity, Arun Joshi, Quest, and Select Novel.

\section{INTRODUCTION:}

In the preceding, an endeavor has been made to concentrate first the idea of existential dilemma, distance and emergency of character concerning the significant Indian English authors and Arun Joshi an appearance of English language in India was a kind of a side-effect of English imperialism (Joshi, 1968). However with the striking of roots, the outsider tongue has been acclimatized and Indianized with the Indian Republic to such a degree which is presently one of the Indian dialects. C. Rajagopalachari cherished English to the point of portraying it as the "endowment of the Goddess Saraswati to India." As this language struck its underlying foundations, writing started to flourish. The nineteenth century anecdotal exposition writing is extremely pitiful and it is purposeless to examine the hints of emergency of personality in the characters present in those works (Hurlock, 1976).

Indeed, even the large three of the Indian English writers, for example, Mulk Raj Anad, R.K.Narayan and Raja Rao, made no significant characters experiencing the emergency of personality or the like or the other (Erich, 1970). Some of the time these focuses develop in R.K. Narayan when he manages the disparities emerging out of the social gorge and the age hole. Manohar Malgaonkar, Kamala Markandaya, BalachandraRajan, ChamanNahal, Ruth Prawar Jhabwala, Anita Desai, Nayantara Sahgal, Salman Rushdie are noticeable authors making characters confronted with the issue of distance and the emergency of personality (Desai,1980). Crafted by these authors have been alluded to in a kind of clearing review after which an 
endeavor has been made to focus upon Arun Joshi's anecdotal manifestations.

Indian English writing is wearing English garments containing inside the Indian body and soul. Be that as it may, even this makes some of the time a sort of unbelievable circumstance in light of the fact that in the western grandeur and show, the individuals overlook themselves in aping the West. This is the consequence of the provincial headache. K.R.S. Iyengar has called "a confounded drifter between the two universes". Some believe that the utilization of English for composing fiction in the Indian setting is a demonstration of imitation (Asnani, 1978). It is best case scenario in a demonstration of interprettation since not many of the Indians think, feel, talk and dream in English. Be that as it may, this please can be overlooked from the perspective of the imaginative portrayal of verisimilitude.

\section{Review of Literature}

Indian English authors need to depict factors concerning the individual, social and national character. The writing written in the language forced upon by certain recorded necessities must be national first. On the off chance that it is national, it additionally reflects naturally the social and individual personality, yet more frequently it has been mocked. It has been quickened by certain sociological and mental variables. It has nearly gotten a typical to assert that the past periods were brilliant, while the present is heavy (Fucrlicht, 1978). In view of this demeanor individuals in each age have respected their occasions to be no man's land. The soul of no man's land is the essential worldview of $20^{\text {th }}$ century mechanical human progress (Atwood, 1970).

Advancements in science and innovation, the material solaces made accessible the contracting of existence, the articulate loss of customary virtues and the scattering of distrust with respect to the otherworldly qualities and a lot increasingly such factors have rendered man a tormented animal. The disappointment with the present material human progress started from places where there is no shortage of any physical needs (Encyclopedia Britannica, 2008). In any case, despite the fact that floundering in the outward plenitude and gaiety, they have been profoundly bankrupt. The developing clique of the flower child wonder and the fame of the UniversePG I www.universepg.com otherworldly restoration under the direction of numerous Indian masters of sorts in the West have been answerable for the carcinogenic development of the idea of destructive distance (Dhawan, 1986).

Every one of these components taken together have made this age a period of tension as well as one of distance. In the Indian setting the rootlessness has risen out of cosmopolitanism, urbanism at the expense of urbanity, deprecating of provincial legacy, usually expected to be rusticity, and the development of an idea of a family unit which has rendered the matured excess (Bible, 1985). Henceforth there has been an ascent in the idea of preposterousness and it is profoundly significant that in a portion of the ludicrous plays the old guardians are tossed to the dustbins.

In The Foreigner Joshi manages a few parts of life on the forlorn planet (Bhatnagar, 1973). Most of these identify with the topics of estrangement, the ludicrous, the corruption and shabbiness of the human presence. Again in the Indian foundation there has been a renaissance of racial cognizance flanking upon the topic of Indianization, which has surfaced after the Parcel holocaust. A significant number of our Indian English writers either know about it or had direct information on it; and in this way, couldn't avoid themselves from depicting the emergency of character conceived out of shortened grounds, deprived families and family members split up past the outskirts. Authors like Chaman Nahal, Khushwant Singh and Salman Rushdie compose their books on the subject of Parcel from this very perspective of the segregation of the battered soul prompting the emergency of the hero.

\section{FINDIGINGS OF THE STUDY:}

Arun Joshi doesn't have a place with this gathering. In spite of the fact that conceived before the Segment of the nation, he didn't encounter this sort of holocaust; and thusly he is for the most part quiet on it. Be that as it may, the emergency looked by his anecdotal characters lies at the more profound layers of the human science and the brain science of humankind. Arun Joshi's topical worry in his books has maybe become out of the positive and negative endless supply of a large number of the American authors and mainland existentialist logicians. It has likewise evolved out of the philosophical vision 
lectured in the perpetual schools of Indian way of thinking and their wantonness with regards to our advanced purchaser culture of the enmasse and the pervasiveness of the anarchic powers. There are occurrences of the mindfulness seeing scholarly way of life also (Identity and the Life Cycle, 1994).

The Foreigner is an original work of Joshi as in all the issues related with the emergency of personality have been taken up for thought in it. The personal account of his life is an examination in rootlessness. His uncle settled in Kenya, similar to Sindi's dad, carries him up with all consideration. Sindi is taught under his uncle's guardianship. Despite the fact that his adolescence is one of wealth, he is aware of the loss of his folks. A significant number of his colleagues continue hassling him with their questions in regards to his folks whom he knows close to figures in wrinkled photos. Khemka in Delhi asks him a similar inquiry and Sindi is helped to remember a similar impression.

The underlying driver of Sindi's disquietude is because of the experience of his lost adolescence. The loss of the two his folks during early stages makes Sindi unbalanced in his character. Notwithstanding the best consideration, his uncle maybe couldn't give him any substitute for the parental love and love. Sindi keeps on being a sort of moving stone till he settles in New Delhi. At all these spots Sindi isn't just disappointed with his parcel yet in addition keeps playing with English and American women and young ladies. Be that as it may, his lifestyle doesn't mitigate either any feeling of weariness or distance in him.

Sindi's character is by all accounts affected by that of Meursault, the hero in The Pariah by Camus. The significant characters in The Outsider get enmeshed in a few features of the emergency of personality. These might be summarized as those having a place with the fields, for example, individual, relational, national, universal, racial and social, modern and business as additionally instructive and phonetic character. The Foreigner arrangements with numerous different subjects, other than the fundamental one. These topics are identified with the defilement in free Indi, tax avoidance, instructive framework, neediness and appetite, the misuse by the business people of the poor workers and even family arranging. In the midst of this confusing of subjects

UniversePG I www.universepg.com
The Outsider is for the most part "a scholarly portrayal of rootlessness." The rootlessness of Sindi in The Outsider is essentially at the socio-mental level. The racial issues surface with regards to mixing of the Indian understudies with the Americans. The Global Understudies' Affiliation masterminded outside understudies' gathering by the local Americans. Be that as it may, regardless of all the altruism with respect to Americans, "all it at any point accomplished was ill will: everyone wound up despising the Americans even more."

The rootlessness of Sindi isn't topographical yet mental. The American young lady June Blyth is directly in her appraisal of his character when she says: "I have an inclination you'd be an outsider anywhere. Sindi is asthmatic in constitution, yet pursues looking for the delights of the substance. His underlying mentality to life is that of "a major deriding zero". The life to him seems, by all accounts, to be purposeless. He talks in the difficulty of an existentialist legend. Unfit to determine the emergency of his personality, he even mulls over suicide and continues evolving places. He takes up certain random temp jobs as a dish-washer and later as a library partner. However he encounters just torment and dream. It is profoundly noteworthy for Sindi and his maker, both having engineering degrees, to state about the mental anxiety of the previous: "Maybe two high voltage terminals had flourished in my mind and every one of them continued parting venom into my cerebrum.

Sindi understands the main driver of his emergency of personality. Being rootless, he has no feeling of ethical quality. "The arbitrariness of presence" drives him towards franticness. Indeed, even his choice to return to India is with the flip of coin wherein the tail represents New Delhi. In The Foreigner, Sindi isn't just the solitary instance of the emergency of personality, even June Blyth experiences a sentiment of vacancy constantly. In her craving she changes accomplices from Sindi to Babu, etc. Babu Rao Khemka has additionally a similar sort of experience. He dreaded about his dad, yet was somewhat open with his sister, Sheila, to whom he continued composition of his American experience of being a tease. Indeed, even June Blyth considers BabuRao's dad to be "a horrendous harasser," since he used to get stressed in the wake of accepting 
letters from him". It is right now he calls Billy "a man of such remarkable fixations".

Individuals when all is said in done and the individuals from his family specifically are at a misfortune to comprehend the activities of Billy's psyche. However Tuula Lindgren, a Swedish specialist, comprehends him splendidly and distinguishes the underlying driver of the emergency of his personality. The life of Billy Biswas is one of peculiar turns and sporadic choices (Billy Biswas, 1971). A quality in his character and internal emergency continue frequenting him. His folks send him to the U.S. to contemplate Engineering, however without their discussion. Billy switches over to the investigation of Anthropology on the grounds that from his very youth he had an exceptionally unmistakable fascination for the innate world (Erickson, 1994). The nearness of the crude power in him prompts him to decide for his home in the U.S. the dark ghetto in Harlem. His enthusiasm for the crude life and a portion of the philosophical issues make him think about a couple of the perpetual issues of the Upanishads: "Who right? Where had I originated from? Where was I going?"

To him the Adivasis had maybe gotten a handle on the soul of the power that provoked the old engineers to construct the sculptural plans of the Konark. Their dull mysterious appearances, to him, contain the shrewdness much past the information and comprehension of the acculturated. Billy, as well, has this crude power which, to Tuula, is uyrkfart. It is this which goes about as a volcanic power in the character of Billy Biswas. Similar to Buddha, Billy neglects his significant other and family to get a handle on the soul of nature while living with the aboriginals. Though Billy is all around settled in his showing calling and favored with his better half, child and guardians, the enlightened society appears to be a lot for him and he keeps on a quest for discharge (Fromm, 2002). His extramarital sex relationship with Rima Kaul is additionally because of the way that she comprehends him obviously superior to his better half, Meena, does. The antagonism among a pair appears as the emergency of Billy's character and as time passes the relationship break down to a degree that, as Meena admits: "he doesn't need me any longer. He hasn't contacted me for a half year. Not once"
Billy's ghastly involvement in the socialized world is answerable for his getaway into the crude world. The humanized society is to Billy: "simply making and going through of cash". Billy's inclinations in the crude in the first place cause him to lose his personality. He has a place neither with the wild of the crude world nor to the astonishing light of the metropolitan. As he continued looking for the genuine self and genuineness, he tries to get a handle on the significance of life. The Strange Case of Billy Biswas says Professor O.P. Mathur "might be taken as a purposeful anecdote of the acknowledgment of one's actual self".

Living with the crude individuals he has a look at the perfect and to the aboriginals he himself accomplishes it. Billy comprehends the higher importance of life, not longed for in the feverish enlightened life. Bimal Biswas at last accomplishes what his name actually signifies: "By chance, the name of the saint, Bimal Biswas, likewise signifies "unadulterated confidence" Billy may have lost his recognize and may have become a confused virtuoso for the cultivated society yet he accomplishes the genuine reason forever".

Billy Biswas' case is fairly not quite the same as Sindi Oberoi's in The Foreigner. While Sindi's character is an investigation in rootlessness, Billy's is nothing of the sort. Romesh Sahai, the storyteller and Billy's companion during the stay in the U.S., affirms this in his clarification: "notwithstanding to some degree long remain aside from over passing spells of dejection, from that estrangement that numerous different Indians appeared to be troubled with". The two offer us relief from their underlying emergency and they look for a sort of improvement in the last arrangement of the issues in question.

\section{CONCLUSION:}

Arun Joshi investigates the emergency of personality, estrangement, rootlessness, those of ethnic, racial, etymological, national, moral, and political in his books that emerge out of despairing in the seventeenth century English writing and still it is considered as a design to present despairing. Building up the way that Joshi's heroes inevitably go through the vague mazes of life, their grabs in obscurity arrive at a finish or something to that affect or the other toward the end. Their existential issues and quandaries are all inclusive and individual; 
however the arrangement is the equivalent. The books of Joshi seem to repeat the interminable and general journey of man for a deliberate and significant presence, and his craving for an otherworldly and social personality. The heroes of his books comprehend the importance of life toward the end and acknowledgment occurs to them. Regardless of his commitment of just five books and a couple of short stories in the Indian-British composition, Arun Joshi appears as a big star in the Indian British writing system.

\section{ACKNOWLEDGEMENT:}

The authors would like to thank the authority of Dept. of English, Muthurangam Government Arts College, Vellore-2, India for their valuable suggestions in writing this article.

\section{CONFLICT OF INTERESTS:}

The authors declare no conflict of interest.

\section{REFERENCES:}

1. Joshi, Arun. (1968). The Foreigner Delhi: Hind Pocket Books, Print. https://shodhganga.inflibnet.ac.in/bitstream/10 603/218300/9/09_chapter\%202.pdf

2. The Strange Case of Billy Biswas, (1971). Delhi: Hind Pocket Books Ltd., Print. https://www.worldcat.org/title/strange-case-ofbilly-biswas/oclc/793256479

3. Asnani, Shyam M. (1978). "A Study of Arun Joshi's Fiction" Literary Half-Yearly 19.2 July: 98-114, Print.

4. Atwood, Margaret. (1970). Afterword. The Journal of Susanna Moodie. Toronto: O.U.P. https://books.google.com.bd/books/about/The Journals_of_Susanna_Moodie.html?id=OSzP AAAAIAAJ\&redir_esc $=y$

5. Bhatnagar, O.P, (1973). "Arun Joshi's" The Foreigner: A Critique of East and West. The Journal of Indian Writing in English, 2: 3843.
6. Hurlock B., Elizabeth. (1976). Personality Development (New Delhi: Tata McGraw Hill.), 41.

7. Desai, Anitha, (1980). Cry The Peacock. New Delhi: Orient Publishers. https://books.google.com.bd/books/about/Cry_ the_Peacock.html?id=TMraDwAAQBAJ\&redi $\underline{\mathrm{r} \text { esc }=\mathrm{y}}$

8. Dhawan, R. K. (1986). The Fictional World of Arun Joshi New Delhi: Classical Publishing Company, Print.

9. Encyclopedia Britannica, (2008). Vol VIII, Chiago: 1962968.

https://digital.nls.uk/encyclopaedia-britanni ca/archive/193108325

10. Ephesians in the Bible. (1985). The New Jerusalem Bible. Ed. Henry Wansbrough. New York: Doubleday, 4-18. http://www.bible-researcher.com/new-jeru salem-bible.html

11. Erickson, Erick. (1994). Identity: Youth and Crisis, 1968, New York: W.W. Norton. https://doi.org/10.1002/bs.3830140209

12. Identity and the Life Cycle, (1994). 1980 New York, London: WW Norton \& Co. https://wwnorton.com/books/Identity-and-theLife-Cycle/

13. Fromm, Erich. (2002). The Sane Society. London: Routledge Classics, ISBN: 13 9780415270984.

14. Erich et al. (1970). Zen Buddhism and Psychoanalysis. New York: Harper and Raw.

https://www.amazon.com/Zen-Buddhism-Psy choanalysis-Erich-Fromm/dp/0060901756

15. Fucrlicht, Ignace. (1978). Alienation from the Past to the Future. Connecticut: Green wood Press, 273 pages.

https://www.amazon.com/Alienation-Past-Fu $\underline{\text { ture-Contributions-Philosophy/dp/03132005 }}$ $\underline{56}$

Citation: Revathy P., and Peruvalluthi V. (2020). Quest and assessment for self-identity in the select Novel of Arun Joshi, Br. J. Arts Humanit. 2(4), 82-86. https://doi.org/10.34104/bjah.020082086 @) 